\title{
Investigating the urban density on social relations
}

\author{
Ghasem Motalebi ${ }^{1}$, Askar Jalalian ${ }^{2}$, Atosa Modiri $^{3}$, Zahra Yazdani $^{3, *}$ \\ ${ }^{1}$ Department of Law, University of Tehran, Tehran, Iran \\ ${ }^{2}$ Department of Law, Payame Noor University, PO BOX 19395 - 3697, \\ Tehran, Iran \\ ${ }^{3}$ Department of Law, Tehran Branch, Islamic Azad University, Tehran, Iran \\ *E-mail address: zahrayazdani1986@gmail.com
}

\begin{abstract}
In modern cities, with changes occurring in the urban environments the social behaviors of the residents have been affected. Some of the changes have weakened social behaviors, while others have reinforced them, such that they impose new social roles on their own residents. According to various perspectives in relation with the urban density (environmental factors), such factors have had an undeniable impact on social relations (social behavior). Also, distinguishing the urban density into two dimensions of constructional and demographic density, the question that arises is: what relation is there between the urban density and social relations?. In the present research, using the document and survey methods and also using a questionnaire for assessing the extent of social communications (residents of the Kashanak neighborhood) information needed was collected. Using the Pearson correlation tests method, data obtained were analyzed and in the end, the results indicated that the intensity of the correlation between the urban density and social relations was low and the type of impact of the constructional and demographic density on social relations was different, so that the impacts of the demographic density was consistent while that of the constructional density was inconsistent. In the end, given the fact the impact mentioned was low but it is non-negligible and it should be attended to in urban planning as an affective factor.
\end{abstract}

Keywords: Urban density; Social relations; Psychology of the environment; Urban planning; Social relations; Correlation

\section{INTRODUCTION}

Today, urbanization is increasingly on the rise which causes an increase in the demographic density. Also, the modern lifestyle is on one hand associated with the urban density and it is associated with cultural diversity on the other hand. Consequently, social relations turn lifeless, fragile and tense. Under such circumstances, collaboration and participation, trusting relations are minimized and the estrangement resulting from the increase density engenders the residents of the neighborhoods and urban areas not to establish meaningful relations among them as in the past. The urban density might be linked with a sense of overcrowding for the residents in a location, resulting in freedom to be lost for the residents and creating stress among them. Of course, this issue differs for different people. For the time being, cities are becoming increasingly dense and the social relations among people pale, such that neighborhoods do not know each other and have no tendency for establishing 
relations. Now, one should investigate the factors affecting the reduced social relations among the residents of the urban areas and for this, one has to understand the impacts of reduced or increased urban density on the social relations of the residents. A reduction of social relations in the modern life has now become a big crisis which results in a loss of life vitality. In the past times, social relations were among the main pillars of cheerfulness and vitality and were deemed spirit of life among the residents. It seems lifestyle and urban density has caused the main pillar (social relations) to be lost. The question arising is that:

What relation is there between the urban density and citizens' social relations?.

The research hypothesis is: increased urban density (demographic and constructional) will reduce social relations.

This hypothesis stresses the correlation between the urban density and social relations.

Investigating the factors affecting social relations from the standpoint of theorists:

Barker $(1963,1968)$, under a title of "psychology of ecology" deals with "meta individual" behavioral patterns as meaning behaviors which are presented collectively and in behavioral bases. He also maintains there is a special relationship between the behavioral and physical dimensions of these bases. He aimed to investigate in the first glance the impacts of the environmental dimensions on collective behaviors. The scholars of the ecologic psychology school have distanced from the laboratory researches and are observing the behavior in natural conditions (Field investigations). Researchers who use "field investigations" serve as a translator. They acquire information through observation and having categorized them, they make them usable and provide it to others and hence, they discover what they don't know. To sum up, Barker maintains, to acquire scientific awareness about the average indices of the psychological phenomena and the diversity of them in the population it is imperative for the behavior to be investigated in its own framework of natural environment. Also, Barker thought of environment as a concrete environment (Mortazavi, 2001).

Ecological pattern or the human social systems pattern: The environment and behavior are so intertwined that they cannot be distinguished. One cannot consider behavior independent from its internal relations with the environment and that behavior should be defined in an environmental basis. This is the most fundamental point in the approach by Barker (1968) and his advocates. Historically speaking, the social and behavioral sciences have investigated people as if they have been separated from their physical environments around them. However, Barker et al have argued that the proper investigation measurement in this area is a measurement which involves the environment and people both (Altman, 2011). Now, to investigate the environment we should categorize the urban spaces existing. John Lang divided the spaces into two environments in terms of invitation to environment: societyoriented and society-avoidant environments (Lang, 2002). The society-oriented environments are spaces which bring people together and society-avoidance environments are the ones that get people separated from each other. Yet, one of the factors in the present research is the formation of a functional centrality of the places and they being situated and non-situated on the path of the daily activities (Lang, 2002). These places are pleasant once they provide comfort and relaxation and allow people to see each other. Such places are public or semipublic areas which are obviously distinguished from each other by symbolic barriers. Activities are among the main subjects that are effective in the environment affecting the behavior and Gel (2008), states that all the activities occurring in the public spaces are dividable in to three categories: necessary, optional and social activities; He also distinguished the relations into three classes:

Sensory relations: close intimacy realrrions, friends

Rational relations: friends, kinsmen and working realrrions 
Daily relations: arbitrary relations, passive relations (audio and visual relations).

Of course, Gel has addressed activities through another perspective where we deal with them in this research in relation with the previous definitions.

Necessary activities-under all circumstances (daily communications): since such activities are necessary and compulsory, their occurrence will be the least influenced by the surrounding environment. These types of activities are done in all occasions of the year and in all circumstances, hence they are more or less independent from the external environments and people have no right to choose (Gel, 2008).

Optional activities-only under favorable conditions (sensory communications): optional activities are once done when there is a tendency to do them and the time and space are conducive to it.

Social activities (rational communications): Social relations involve activities which are dependent on the presence of others in public spaces more than anything else.

In regard to communications, Stephan Carr, one of the modern theorists argues relations could be divided into two classes of active and non-active participation:

Non-active participation (communication) that could help people feels relaxed and comfortable in the space. It provides the need to encounter and get engaged with the environment, though non-actively. The most primary form of the non-active participation is people viewing: that which attracts people to the space. Active participation (communication) which involves a direct and closer experience with the space and people present in it. It is noteworthy that although some people enjoy watching others, mos6 are interested in establishing a closer contact with their friends, be kinsmen or strangers (Karmona et al, 2012).

Overcrowding: Two concepts of "density" and "overcrowding" are closely interrelated and some psychologistst apply these two concepts interchangeably. For Daniel Stokols, density means the "ratio of number of people to a unit of land". It is reminded that density is a concrete description and "overcrowding" is a phenomenon subject to the personal experience. Although the population density contributes significantly to the feeling of overcrowding, this feeling is a subjective phenomenon, because it is influenced by some psychological factors on one hand and environmental and cultural factors on the other hand. There are substantial differences between people and social communities in terms of feeling and tolerance of overcrowding, such that some people prefer to live in crowded areas and yet some others feel crowded even in less densely populated areas.

Density: It can be defined as a measurement system that enables us to define and estimate the number of people mathematically and simply in a certain level of land as population density or as the extent of area located in a certain level of land as the constructional density. Classification in terms of density measurement unit leads to the recognition of two types of density, i.e. constructional and demographic density. In fact, density can be measured in terms of their measurement units into two types, i.e. the demographic density which is estimated by person or household unit per hectare or the constructional density. Also, density could be classified based on intensity and its size and hence different types of low, average and high density could be differentiated. While the notion of density could be expressed clearly, hence classification of its intensity and size absolutely and certainly seem problematic. In fact, that which renders in the adjective of low, high and average to the term density depends on various factors which have a relative nature themselves. Of the factors, we can refer to proportion and residential culture of a city or special country, the location of the project and type of the building (Tarantash, 2009).

Distances and communications: The interaction between the intensity and distance of sensory perceptions are widely applied in human relations. Strong sensory relations occur in a 
close distance between 0 to half a meter, while weaker communications occur in a distance more than half a meter to 7 meters. Knowingly using of the distance exists in almost all communications. The distance between the participating people if the two parties are inclined could be reduced and added to the intensity of the relations. Conversely, if intensity and interest are reduced the distance will increase.

\section{TYPES OF DISTANCES}

Intimate distance: $(0-45 \mathrm{~cm})$ it is a distance in which extreme feelings are expressed: kindness, comforting (condoling), love and also extreme anger (Gel, 2008).

Social distance: (1/30-3/75) it is a distance for the normal conversation of friends, kinsmen and colleagues and the like. Handle chairs and coffee tables represent a social distance.

Public distance: (more than $3 / 75 \mathrm{~m}$ ) it is a distance defined for more official occasionslike teachers while teaching and one-way communications when the person wants to see or hears an event without engaging in it.

\section{METHODOLOGY}

In the psychology of the environment, field researches and experiments are preferred over laboratory experiments. This method helps the external validity and this is once fulfilled when research findings are with some more certainty generalized to a real situation of events. Barker maintains, to acquire scientific awareness about the average indices of the psychological phenomena and the diversity of them in the population it is imperative for the behavior to be investigated in its own framework of natural environment (Biker, 1998). In the present research, using the document and survey methods and also using a questionnaire for assessing the extent of social communications (residents of the Kashanak neighborhood) information needed was collected. Using the Pearson correlation tests method, data obtained were analyzed(Ahmadi, 2012). Among the various techniques for collecting data, the survey questionnaires are thought to have the highest application in correlation based researches, because they allow for widespread data collection about demographic characteristics and behavioral habits, attitudes and belifs about different subjects from among a wide population in the least time possible (Gerout \& Wank, 2009).

The questionnaire available was adjusted based on the Likert scale. Then by using statistical methods, it was transformed into quantitative variables so that advanced statistical tests are used and research findings are made applicable. In this research descriptive statistical techniques, including frequency table and bar graph were used for analyzing the data and using the SPSS software, the validity of the research hypothesis based o the Pearson correlation coefficients were addressed. The sampling method was the probability (random) classification sampling. The main goal of the probability (random) sampling is to choose and collect the data such that the results are generalized to a larger population by measuring the error margins (determined by statistical methods). The probability (random) sampling, because it is based in inferential statistical methods is preferred over other methods. Thus, in this research residents were randomly selected, of course such factors as gender (male and female) and age $(15+)$ were considered and the sample selection was purposive. 
Table 1. Components and information of measurable indices.

\begin{tabular}{|c|c|c|c|c|c|c|}
\hline Components & $\begin{array}{c}\text { Measurement } \\
\text { indices }\end{array}$ & $\begin{array}{l}\text { Types } \\
\text { of index }\end{array}$ & $\begin{array}{c}\text { Measurement } \\
\text { level }\end{array}$ & $\begin{array}{c}\text { Collection } \\
\text { method }\end{array}$ & $\begin{array}{c}\text { Cited } \\
\text { source }\end{array}$ & Operational definition \\
\hline \multirow{4}{*}{$\begin{array}{c}\text { Urban } \\
\text { density- } \\
\text { overcrowding } \\
\text { (dependent } \\
\text { variable) }\end{array}$} & \multirow{4}{*}{$\begin{array}{c}\text { Peoples' } \\
\text { distance from } \\
\text { each other } \\
\text { Far (1) } \\
\text { Relatively } \\
\text { far(2) } \\
\text { Neither far } \\
\text { nor close (3) } \\
\text { Relatively } \\
\text { close (4) } \\
\text { Close (5) }\end{array}$} & Intimate & Rank-based & Questionnaire & $\begin{array}{c}\text { Jon } \\
\text { Gel } \\
(2008)\end{array}$ & $\begin{array}{l}(0-45 \mathrm{~cm}) \text { it is a distance } \\
\text { in which extreme } \\
\text { feelings are expressed }\end{array}$ \\
\hline & & Social & Rank-based & Questionnaire & $\begin{array}{c}\text { Jon } \\
\text { Gel } \\
(2008)\end{array}$ & $\begin{array}{c}1 / 30-3 / 75) \text { it is a } \\
\text { distance for the normal } \\
\text { conversation of friends, } \\
\text { kinsmen and colleagues } \\
\text { and the like. }\end{array}$ \\
\hline & & Public & Rank-based & $\begin{array}{c}\text { Questionnaire } \\
\text { and } \\
\text { observation }\end{array}$ & $\begin{array}{c}\text { Jon } \\
\text { Gel } \\
(2008)\end{array}$ & $\begin{array}{l}\text { (more than } 3 / 75 \mathrm{~m} \text { ) it is a } \\
\text { distance defined for } \\
\text { more official occasions- } \\
\text { like teachers while } \\
\text { teaching and one-way } \\
\text { communications when } \\
\text { the person wants to see } \\
\text { or hears an event } \\
\text { without engaging in it. }\end{array}$ \\
\hline & & $\begin{array}{c}\text { Interper } \\
\text { sonal }\end{array}$ & Rank-based & Questionnaire & $\begin{array}{c}\text { Altman } \\
(2011)\end{array}$ & $\begin{array}{l}\text { It is a result of } \\
\text { overcrowding where the } \\
\text { increase of distance for } \\
\text { Gifford is one of the } \\
\text { methods for separation } \\
\text { of people from densely } \\
\text { populated Areas. In } \\
\text { densely populated areas } \\
\text { people have a distance } \\
\text { from each other and the } \\
\text { social relations are low. }\end{array}$ \\
\hline
\end{tabular}

Table 2. Components and information of measurable indices.

\begin{tabular}{|c|c|c|c|c|c|}
\hline Components & Measurement indices & $\begin{array}{c}\text { Measurement } \\
\text { level }\end{array}$ & $\begin{array}{c}\text { Collection } \\
\text { method }\end{array}$ & $\begin{array}{l}\text { Cited } \\
\text { source }\end{array}$ & Operational definition \\
\hline \multirow{4}{*}{$\begin{array}{c}\text { Urban } \\
\text { density } \\
\text { (independent } \\
\text { variable) }\end{array}$} & $\begin{array}{c}\text { Human scale } \\
\text { (movement type) }\end{array}$ & Rank-based & Questionnaire & $\begin{array}{l}\text { Jon Gel } \\
\text { (2013) }\end{array}$ & $\begin{array}{l}\text { Low speed, small } \\
\text { dimensions and exact } \\
\text { details and on foot } \\
\text { movement are } \\
\text { interdependent, creating } \\
\text { less distance and more } \\
\text { intimate relations which } \\
\text { indicates a human scale }\end{array}$ \\
\hline & $\begin{array}{l}\text { Population (number of } \\
\text { household, number of } \\
\text { children, dimension of } \\
\text { household and } \\
\text { population density) }\end{array}$ & $\begin{array}{l}\text { Distance- } \\
\text { based }\end{array}$ & $\begin{array}{l}\text { Questionnaire } \\
\text { and } \\
\text { document } \\
\text { information }\end{array}$ & $\begin{array}{l}\text { Azizi } \\
(2009)\end{array}$ & $\begin{array}{c}\text { Demographic density: } \\
\text { population at the surface } \\
\text { level and usually person } \\
\text { per hectare } \\
\text { Household dimension: } \\
\text { population divided by the } \\
\text { number of households }\end{array}$ \\
\hline & $\begin{array}{l}\text { Structural features } \\
\text { (constructional density, } \\
\text { number of stories, } \\
\text { metrage and number of } \\
\text { residential flats) }\end{array}$ & $\begin{array}{l}\text { Distance- } \\
\text { based }\end{array}$ & $\begin{array}{l}\text { Questionnaire } \\
\text { and } \\
\text { document } \\
\text { information }\end{array}$ & $\begin{array}{l}\text { Azizi } \\
(2009)\end{array}$ & $\begin{array}{l}\text { The area surface of the } \\
\text { building to the area of the } \\
\text { flat is the constructional } \\
\text { density }\end{array}$ \\
\hline & Functional centrality & Nominal & $\begin{array}{l}\text { Questionnaire } \\
\text { and } \\
\text { document } \\
\text { information }\end{array}$ & $\begin{array}{c}\text { John } \\
\text { Lang(2002) }\end{array}$ & $\begin{array}{l}\text { Place situated on the path } \\
\text { of the daily activities. } \\
\text { These places provide } \\
\text { comfort and relaxation } \\
\text { for people }\end{array}$ \\
\hline
\end{tabular}


Table 3. Components and information of measurable indices.

\begin{tabular}{|c|c|c|c|c|c|c|}
\hline Components & $\begin{array}{l}\text { Measurement } \\
\text { indices }\end{array}$ & $\begin{array}{l}\text { Types of } \\
\text { indices }\end{array}$ & $\begin{array}{c}\text { Measurement } \\
\text { level }\end{array}$ & $\begin{array}{c}\text { Collection } \\
\text { method }\end{array}$ & $\begin{array}{c}\text { Cited } \\
\text { source }\end{array}$ & $\begin{array}{c}\text { Operational } \\
\text { definition }\end{array}$ \\
\hline \multirow[t]{3}{*}{$\begin{array}{c}\text { Social } \\
\text { relations } \\
\text { (dependent } \\
\text { variable) }\end{array}$} & \multirow[t]{3}{*}{$\begin{array}{l}\text { Activities } \\
\text { (active and } \\
\text { non-active) }\end{array}$} & $\begin{array}{c}\text { Daily } \\
\text { (non-active } \\
\text { and } \\
\text { necessary) }\end{array}$ & $\begin{array}{l}\text { Distance- } \\
\text { based }\end{array}$ & Questionnaire & $\begin{array}{c}\text { Jon } \\
\text { Gel } \\
(2008)\end{array}$ & $\begin{array}{l}\text { that could help } \\
\text { people feel relaxed } \\
\text { and comfortable in } \\
\text { the space. } \\
\text { It provides the need } \\
\text { to encounter and get } \\
\text { engaged with the } \\
\text { environment, though } \\
\text { non-actively. The } \\
\text { most primary form } \\
\text { of the non-active } \\
\text { participation is } \\
\text { peoples' viewing: } \\
\text { that which attracts } \\
\text { people to } \\
\text { the space. They are } \\
\text { compulsory and We } \\
\text { have to participate } \\
\text { In them, They are } \\
\text { least Influenced by } \\
\text { the surrounding } \\
\text { environment }\end{array}$ \\
\hline & & $\begin{array}{c}\text { Sensory } \\
\text { (active and } \\
\text { optional ) }\end{array}$ & $\begin{array}{l}\text { Distance- } \\
\text { based }\end{array}$ & Questionnaire & $\begin{array}{c}\text { Jon } \\
\text { Gel } \\
(2008)\end{array}$ & $\begin{array}{l}\text { There is a tendency } \\
\text { To do it and they } \\
\text { occur Only when } \\
\text { external Conditions } \\
\text { Are conducive }\end{array}$ \\
\hline & & $\begin{array}{l}\text { Rational } \\
\text { (active and } \\
\text { social) }\end{array}$ & $\begin{array}{l}\text { Distance- } \\
\text { based }\end{array}$ & Questionnaire & $\begin{array}{c}\text { Jon } \\
\text { Gel } \\
(2008)\end{array}$ & $\begin{array}{c}\text { They are dependent } \\
\text { on Peoples' } \\
\text { participation. Social } \\
\text { relations Are } \\
\text { supported where } \\
\text { Sensory and daily } \\
\text { Activities Are } \\
\text { provided. }\end{array}$ \\
\hline
\end{tabular}

\section{SAMPLE}

The Kashanak neighborhood is located in the north eastern part of Tehran and is in a good situation. Here, in this neighborhood there are various forms of buildings, but due to high steep in parts of the neighborhood (older and central part) the structure is worn out and most the flats are in form of cottage and two story flats. This neighborhood is an area with low constructional density and average demographic density. In other parts of the neighborhood buildings with average height indicates a higher constructional density, while in terms of demographic density it is in a low level and generally the neighborhood under study has different constructional and demographic density. This incongruity resulted in the selection of this part in the city for the present research. 


\section{RESULTS}

Table 4. The neighborhood population as distinguished by gender.

\begin{tabular}{|c|c|c|c|}
\hline Gender & No. (person) & Total population & $\begin{array}{c}\text { Total population } \\
\text { over 15 years }\end{array}$ \\
\hline Female & 9221 & 18079 & 15734 \\
\hline Male & 888 & & \\
\hline
\end{tabular}

Investigating the questionnaire questions and analyzing them:

Gender: By the time of completing the questionnaire, attempts were made to choose men and women equally but due to existing limitations and problems and lack of tendency on the part of men to answer the questionnaire their number was reduced to around 5\% compared to women.

Income level: In accordance with the answers of the Kashanak neighborhood residents to the questionnaire, we conclude they are at a medium range income level and in the second stage there were people with relatively high economic situation. This point was identifiable given the observation of the researchers.

Age: The maximum age of the respondent was 80 and the minimum was 16 years of age. The highest number of respondents was in the age range of 31-45 years.

Residency time duration: It appears the residency time duration is one of the factors that affects the type and intensity of the social communication because the more the residency time duration the better people will come to establish communications with others. The highest time duration for residency in there was 61 years while the eats time duration was 1 year.

The highest number of flat stories was between 3-5 stories while in the second stage it was between 1-2 stories.

Household dimension: Number of household people was between 3-4 people and in accordance with the information collected by the Iran's statistics center in 2012, the household dimension was 3/037 people, indicating the truth of the respondents' answers.

Residential flat area: Most residents were living in a residential flat with a area of 50100 square meters and in the second stage they were living in 100-150 square meters, indicating average economic situation of the residents.

Number of residential flats: Number of residential flats in each story specifies the number of household living in an apartment and it is used in estimating the demographic density. Overcrowding and rush: In the first stage the neighborhood was tranquil and quiet in terms of men and women while in the second stage it was overcrowded by men and women. The neighborhood was relatively quiet in accordance with findings by the researcher. Extent of peoples' distance: Most respondents tended to establish communications with one another in a relatively close distance, indicating peoples' tendency for relations. Familiarity with neighbors: Most people have little familiarity with their neighbors, of course men than women were more inclined to know their neighbors.

Participation in ceremonies: Men are most often participating in the ceremonies, but women have little tendency to participate in the ceremonies. In this neighborhood there is old mosque and a Husseiniye for gathering of the people in there. Assistance to others: Most 
people are inclined to help others. This indicates people if situation is prepared will tend to establish relations with others and help them. Public spaces: Given the information collected, there is a no public space for the northern part of the neighborhood, indicating a lack of functional centrality. However, in the southern part there are relatively appropriate public spaces for the people. Residents' communication extent: The people in the area have an appropriate relation with one another. Of course, women were more favorable of this subject than men. This issue shows that people in the neighborhood are interested in establishing relations with others.

Extent of expressing problems with the neighbors: Most female respondents were unwilling to express their problems with others but men did, which means men compared to women are more willing to express their problems and they seem to be more successful.

Type of establishing communication in the neighborhood: Most women meet with their neighbors for discussing daily works, but men are in constant relations with one another.

Spending time with neighborhood people: Based on the data, women seldom spend their daytime hours with their neighbors, but men due to their situation spend more time along with their counterparts.

Table 5. Level of feeling of overcrowding and constructional density.

\begin{tabular}{|c|c|c|c|c|c|c|}
\hline \multirow{2}{*}{ Total } & \multicolumn{5}{|c|}{ Overcrowding } & \multicolumn{2}{c|}{$\begin{array}{c}\text { Feeling of overcrowding } \\
\text { and constructional } \\
\text { density (No.) }\end{array}$} \\
\cline { 2 - 7 } & Quiet & $\begin{array}{c}\text { Relatively } \\
\text { quiet }\end{array}$ & $\begin{array}{c}\text { Neither } \\
\text { overcrowded } \\
\text { or quiet }\end{array}$ & $\begin{array}{c}\text { Relatively } \\
\text { overcrowded }\end{array}$ & Overcrowded & \multicolumn{2}{c|}{$\begin{array}{c}\text { Low: } 60- \\
240\end{array}$} \\
\hline 17 & 11 & 22 & 10 & 18 & 0 & $\begin{array}{c}\text { High: } 300- \\
\text { Constructio } \\
\text { nal density }\end{array}$ \\
\hline 18 & 13 & 31 & 1 & 520 & 2 & Total \\
\hline
\end{tabular}

It seems that people living in low and high constructional density have no feeling of overcrowding and for them the neighborhood is relatively quiet which indicates that the neighborhood despite the different constructional density does not resonate a feeling of overcrowding.

Table 6. Level of feeling of overcrowding and demographic density.

\begin{tabular}{|c|c|c|c|c|c|c|c|}
\hline \multirow{3}{*}{$\begin{array}{c}\text { Total } \\
53\end{array}$} & \multicolumn{5}{|c|}{ Overcrowding } & \multirow{2}{*}{\multicolumn{2}{|c|}{$\begin{array}{l}\text { Feeling of overcrowding } \\
\text { and constructional } \\
\text { density (No.) }\end{array}$}} \\
\hline & Quiet & $\begin{array}{l}\text { Relatively } \\
\text { quiet }\end{array}$ & $\begin{array}{c}\text { Neither } \\
\text { overcrowded } \\
\text { or quiet }\end{array}$ & $\begin{array}{l}\text { Relatively } \\
\text { overcrowded }\end{array}$ & Overcrowded & & \\
\hline & 12 & 19 & 5 & 15 & 2 & $\begin{array}{c}\text { Low: } \\
140-400\end{array}$ & \multirow{2}{*}{$\begin{array}{l}\text { Demographi } \\
\text { c density }\end{array}$} \\
\hline 27 & 1 & 12 & 6 & 8 & 0 & $\begin{array}{c}\text { High: } \\
\text { 410-900 }\end{array}$ & \\
\hline 80 & 31 & 31 & 11 & 23 & 2 & \multicolumn{2}{|c|}{ Total } \\
\hline
\end{tabular}


It seems that people living in low and high demographic density have no feeling of overcrowding and for them the neighborhood is relatively quiet which indicates that the neighborhood despite the different demographic density does not resonate a feeling of overcrowding.

Table 7. Correlation coefficient level and the consistency of the variables.

\begin{tabular}{|c|c|c|c|}
\hline $\begin{array}{c}\text { Social relations } \\
\text { (dependent variable) }\end{array}$ & $\begin{array}{c}\text { Pearson correlation } \\
\text { coefficients }\end{array}$ & Sig. & Correlation type \\
\hline $\begin{array}{c}\text { Constructional } \\
\text { density(independent } \\
\text { variable) }\end{array}$ & $-0 / 280$ & $0 / 012$ & Inconsistent \\
\hline $\begin{array}{c}\text { Demographic } \\
\text { density(independent } \\
\text { variable) }\end{array}$ & $0 / 238$ & $0 / 033$ & Consistent \\
\hline
\end{tabular}

Correlation between the urban density variable and social relations has been low but it is nonnegligible and should be attended to.

\section{CONCLUSION}

Here, in this part we address the main question and hypothesis expressed:

To answer the question we can say that there is an inverse relationship between the constructional density and social relations and there is a direct relationship between the demographic density and social relations, but this relationship is little and should be attended to. This issue should be considered in the urban planning. The application of the research for the urbanization and urban planning: Urban planners could by using the existing potentials and investigating the factors affecting the social relations provide plans for avoiding reduced social relations. These planning could add to the intensity of the social and emotional relations paling in the cities. It appears there are some factors besides the unconventional building and constructions effective in reducing social relations where the planners should pay attention to them and assess them for construction. Planners could by using the participation try to change and improve the situation, because any of the factors affecting the social relations could expose different results. Such factors as ethnicity, customs, life styles and the like are different in the neighbors and have left different impacts on social relations. For this, each of these factors should be analyzed in their own respects.

\section{References}

[1] Ahmadi, M. (2012). Methodology (principles and concepts with the approach of the dissertation). Sari: Cultural Research publication.

[2] Altman, I. (2011). Environment and social behavior-privacy, personal space, realm, overcrowding (Translated by Ali Namazi). Tehran: Shahid Beheshti University publication.

[3] Azizi, M. M. (2009). Density in urban construction- principle and criteria for determining the urban density. Tehran: Tehran University publication. 
[4] Biker, T. (1998). The social research. (Translated by Naeeni Hoshang). Tehran: procedures publication.

[5] Gel, J. (2008). Life in the spaces between buildings. (Translated by Shima Shasti). Tehran: Jihad Daneshgahi publication.

[6] Gel, J. (2013). Human city (Translated by Ali and Leila Ghafoori). Elm Me'mar institute Publication.

[7] Gerout, L., \& Wank, D. (2009). Research Methods in Architecture. (Translated by Shima Shasti). Tehran: Tehran University publication.

[8] Karmona, M., Hitt, T., Tnrak, T., \& Sytven, M. (2012). Public places, urban spaces. (Translated by Gharayi et al). Tehran: Tehran Art University publication.

[9] Lang, J. (2002). Creation of architecture art. (Translated by Alireza Eini far). Tehran: Tehran University publication.

[10]Mortazavi, Sh. (2001). Environment psychology and its application. Tehran: Shahid Beheshti University publication.

[11]Tarantash, M. (2009). A comparative study of high density and vitality. Master's thesis, degree of urbanization, Science \& Technology. Tehran, Islamic Azad University, Tehran. 